READER'S OPINION AND DISCUSSION

\section{Are all psittacine birds carriers of Cryptococcus neoformans?}

\section{Guilherme Augusto Marietto-Gonçalves ${ }^{1 /+}$, Fabrizio Grandi ${ }^{2,3}$}

\author{
${ }^{1}$ Laboratório de Ornitopatologia ${ }^{2}$ Laboratório de Patologia \\ Investigativa e Comparativa, Departamento de Clínica Veterinária, \\ Faculdade de Medicina Veterinária e Zootecnia \\ ${ }^{3}$ Departamento de Patologia, Faculdade de Medicina de Botucatu, \\ Universidade Estadual Paulista, Botucatu, SP, Brasil
}

We read with great interest the article entitled "First isolation of Cryptococcus gattii molecular type VGII and Cryptococcus neoformans molecular type VNI from environmental sources in the city of Belém, Pará, Brazil". The report describes the most recent observation of the presence of Cryptococcus in the normal microbiota of healthy psittacine birds maintained in captivity in Brazil, similarly to the results of Abegg et al. (2006), who identified this yeast in Aratinga leucophthalmus, Aratinga aurea, Aratinga jandaya, Pionus maximiliani, Nymphicus hollandicus, Psittacula eupatria, Nandayus nenday, Amazona festiva, Amazona rhodocorytha and Amazona farinose. Lugarini et al. (2008) also found this yeast in Melopsittacus undulatus and Myiopsitta monachus and Santos et al. (2009) found it in Aratinga solstitialis and Amazona aestiva. Despite the number of reported species harbouring Cryptococcus, Costa et al. (2009) did not report the species of birds in which Cryptococcus was isolated. Thus, readers could misinterpret this report and assume that all psittacine birds are carriers of this yeast. In addition, the citation of this article might compromise future surveys. We would like to suggest to the editors that an additional note be published that addresses this matter because the detection of Cryptococcus in previously undescribed species has great importance in terms of public health given its potential to cause disease.

\section{REFERENCES}

Abegg MA, Cella FL, Faganello J, Valente P, Schrank A, Vainstein MH 2006. Cryptococcus neoformans and Cryptococcus gattii isolated from the excreta of Psittaciformes in a southern Brazilian Zoological Garden. Mycopathol 161: 83-91.

Costa SPSE, Lazéra MS, Santos WRA, Morales BP, Bezerra CCF, Nishikawa MM, Barbosa GG, Trilles L, Nascimento JLM, Wanke B 2009. First isolation of Cryptococcus gattii molecular type VGII and Cryptococcus neoformans molecular type VNI from environmental sources in the city of Belém, Pará, Brazil. Mem Inst Oswaldo Cruz 104: 662-664.

+ Corresponding author: gmarietto_ornito@fmvz.unesp.br

Received 26 May 2011

Accepted 23 September 2011
Lugarini C, Goebel CS, Condas LAZ, Muro MD, Farias MR, Ferreira FM, Vainstein MH 2008. Cryptococcus neoformans isolated from passerine and psittacine bird excreta in the state of Paraná, Brazil. Mycopathol 166: 61-69.

Santos LL, Ferreira FM, Lopes SF, Condas LA, Muro MD, Lugarini C 2009. Pesquisa de Cryptococcus neoformans e Candida spp em excretas de psitacídeos e passeriformes cativos. Arq Cienc Vet Zool Unipar 12: 5-9.

\section{REPLY}

In fact, the C. neoformans molecular type VNI strain collected from a commercial aviary in the city of Belém by Costa et al. (2009) was isolated from the excreta of caged budgerigars (M. undulatus). It is also important to note that Cryptococcus was not isolated in the "normal microbiota of psittacine birds maintened in captivity" but just from dried bird excreta (faeces plus urine) that had accumulated on the tray. Thus, the yeast was isolated from the external microenvironment of these bird cages. Actually, there is a mistake in supposing that the pathogenic species of Cryptococcus isolated by Abegg et al. (2006), Lugarini et al. (2008) and Santos et al. (2009) were present in the normal microbiota of healthy psittacine birds maintained in captivity. Their yeast isolations were done from the excreta of birds of the listed species kept in captivity. We did not affirm that the caged psittacinae were carriers of Cryptococcus, but merely noted the presence of this pathogenic yeast in their excreta exposed to external environmental conditions. It has been widely demonstrated that the contamination of such environments contributes to the aerial dispersion of propagules of C. neoformans, thus allowing their transmission to humans and other mammals. Moreover, it is important to note that cryptococcosis is not a zoonotic infection and that humans and other animals may be contaminated, colonised or infected, depending on their susceptibility.

The occurrence of $C$. neoformans in bird excreta is essentially a saprobiotic phenomenon, without any specificity for a particular bird species. Therefore, the isolation of $C$. neoformans from the excreta of a particular bird species does not necessarily mean that this vertebrate is a host or a carrier of the yeast. Sites shielded from direct sunlight and ultraviolet light in which substrata rich in urea and other nitrogenous sources accumulate, high avian density and poor hygiene are likely to become contaminated microenvironment by Cryptococcus. Pigeon habitats in urban environments are the most studied sources of Cryptococcus throughout the world (Mitchell et al. 2011). Crop colonisation and mechanical transport through external contamination of pigeon feathers and feet by $C$. neoformans has been reported, but more studies are necessary to determine importance of pigeons in the transmission of these yeasts to humans and other mammals. In addition, the droppings of caged birds [such as Paroaria dominicana (red-cowled cardinal), Serinus canarius, Serinus flaviventris (yellow canary), Sicalis flaveola (saffron finch), Sporophila caerulescens (double-collared seedeater)] kept in domestic environments in Rio de Janeiro showed $12.7 \%$ positivity 
(10/79) for C. neoformans (Passoni et al. 1998). Besides the domestic environments, commercial stores that sell birds are prone to harbour $C$. neoformans due the high frequency of the conditions described above. For instance, in the city of Campo Grande, Mato Grosso do Sul, a study of bird droppings identified C. neoformans serotype A in cages of budgerigars in a commercial store (Filiú et al. 2002). The original and natural budgerigar habitats are not necessarily positive for $C$. neoformans. Pigeon excreta are the most common known environmental reservoir of $C$. neoformans VNI and the excreta of captive budgerigars are also a potential source for this molecular type depending on local micro-environmental factors, especially available nutrient sources and physical conditions. Finally, we emphasise that the isolation of C. neoformans from bird excreta collected in the environment in which they live, in nature or in captivity, does not mean that a particular bird species has as specific role as a reservoir or that this fungus is part of the natural microbiota of these vertebrates. Furthermore, there is no scientific evidence that the fungus has the ability to grow or survive in the excreta of a specific bird.

\section{REFERENCES}

Costa SPSE, Lazéra MS, Santos WRA, Morales BP, Bezerra CCF, Nishikawa MM, Barbosa GG, Trilles L, Nascimento JLM, Wanke B 2009. First isolation of Cryptococcus gattii molecular type VGII and Cryptococcus neoformans molecular type VNI from environmental sources in the city of Belém, Pará, Brazil. Mem Inst Oswaldo Cruz 104: 662-664.

Filiú WFO, Wanke B, Agüena SM, Vilela VO, Macedo RCL, Lazera M 2002. Cativeiro de aves como fonte de Cryptococcus neoformans na cidade de Campo Grande, Mato Grosso do Sul, Brasil. Rev Soc Bras Med Trop 35: 591-595.

Mitchell TG, Catañeda E, Nielsen K, Wanke B, Lazera MS 2011. Environmental niches for Cryptococcus neoformans and Cryptococcus gattii. In J Heitman, TR Kozel, KJ Kwon-Chung, JR Perfect, A Casadevall (eds.), Cryptococcus from human pathogen to model yeast, ASM Press, Washington, p. 237-260.

Passoni LFC, Wanke B, Nishikawa MM, Lazera MS 1998. Cryptococcus neoformans isolated from human dwellings in Rio de Janeiro, Brazil: an analysis of the domestic environment of AIDS patients with and without cryptococcosis. Med Mycol 36: 305-311.

Bodo Wanke

Márcia dos S Lazéra

Laboratório de Micologia, Instituto de Pesquisa Clínica Evandro

Chagas-Fiocruz, Rio de Janeiro, RJ, Brasil

Solange do Perpétuo Socorro Evangelista Costa Instituto de Ciências Biológicas, Universidade Federal do Pará, Belém, PA, Brasil 